\title{
The Application of Support Mechanisms to Increase the Success of Aboriginal Students
}

\author{
Randy Herrmann, P.Eng. \\ University of Manitoba \\ herrmann@cc.umanitoba.ca
}

\begin{abstract}
Engineering Access Program at the University of Manitoba has been in existence since 1985. It started with the mandate to improve the recruitment and retention of Aboriginal people in the Faculty of Engineering by introducing a selection of supports to these students.

In order to improve the recruitment of Aboriginal students the requirements necessary for them to enter engineering have been lowered while keeping the requirements to obtain a degree the same.

In order to lower the entrance requirements upgrading (or preparatory) courses were introduced into the program.

In addition to the upgrading courses Student supports in ENGAP are comprised primarily of academic support, social support, financial aid, and personal support.

In addition to the support network prospective students must attend a mandatory summer orientation aimed at preparing them for University studies.

ENGAP has been very successful and now boasts 85 graduates of Aboriginal descent that work throughout the western provinces in various areas.
\end{abstract}

Keywords: engineering education, supports, Aboriginal,

\section{INTRODUCTION}

The Engineering Access Program (ENGAP) began in 1985 through a joint initiative between the federal and provincial governments. Since that time the program has undergone significant changes most notably when the federal government completely cut funding in the early 1990's. Since 1998 the funding stream has been secured through the provincial government and the program has stabilized.

There are five main aspects that make the ENGAP program successful,

- recruitment of Aboriginal students

- an in-depth interview process of prospective candidates
- $\quad$ summer orientation

- upgrading/preparatory courses

- $\quad$ supports

ENGAP has been very successful and now boasts 85 graduates in various engineering disciplines.

\section{BACKGROUND}

It is a fact that Aboriginal people are underrepresented in post-secondary education and almost non-existent in science, technical, engineering and math fields (STEM).

A larger percentage of Aboriginal people do not graduate from high school and often those that do, do not have the proper high school credits (or do not have a sufficiently high enough average) to enter into an engineering faculty in Canada. Oftentimes because of this unsuccessful high school experience they do not feel comfortable attempting postsecondary education until they are older.

As older students they are often living on their own or even caring for families. And again because of their previous lack of educational attainment they are often working in marginal, low wage jobs. This adds another degree of financial burden that most engineering students do not face.

Given the dearth of Aboriginal engineers makes mentorships and role models almost non-existent.

Couple this with often very serious transitional issues such as leaving home and community for the first time to live hundreds of kilometers away in a large urban centre and you are sowing the seeds for failure.

\section{RECRUITMENT}

A very important part of the program is the recruitment of Aboriginal students. Staff members routinely travel throughout Manitoba speaking to high school students in 
their classrooms and also at career fairs. In the recent past staff members have traveled as far away as Iqaluit in the northeast and Yellowknife in the northwest to encourage Aboriginal students into engineering.

Being part of the Aboriginal community, however, is as important as the recruitment of students. ENGAP has aimed math and science initiatives at children as young as Kindergarten. Whenever asked ENGAP supports the Aboriginal community by sitting on boards or committees or by donating items for special events like Elder's Gatherings or Pow-Wows.

\section{INTERVIEW}

ENGAP employs a lengthy application form that seeks to get a thorough history of the student. The applicant is asked questions on personal, familial, financial, academic and job history. The application includes a written autobiography.

After the applications are reviewed each student will be invited to an interview. A standardized interview of 15 questions that helps to determine the prospective student's interest in engineering and motivation to succeed is used. The interview is also used to inform the students of the engineering program and the commitment needed to complete it.

The interviews are conducted by the Director, Academic Advisor, and the Personal Counsellor, as well as one invited engineering professor. At the end of each day of interviews a presentation on ENGAP and on University expectations is given. Students are encouraged to bring their families to this presentation. Staff review the personal commitment required of student to obtain an engineering degree (ie attending classes, doing assignments, committing time to studying outside of class, etc) and the supports offered by ENGAP.

\section{SUMMER ORIENTATION}

During the last two weeks of August new ENGAP students take part in a summer orientation. The goal of summer orientation is to prepare students for university studies and covers such subjects as computer skills, University orientation, writing skills, calculator skills, study skills, as well as a preliminary math course.

Summer orientation runs from 9:00 am until 4:30 pm every day and at the end of the orientation students are assessed based on numerous criteria such as: attendance, completion of work, attitude, and academic ability.
The objectives of the summer orientation are to;

- Develop and improve learning skills

- Develop a relationship with and among students

- Build self confidence

- Develop a clear understanding of ENGAP, engineering, and University policies

- $\quad$ Adjust to the city

- Develop reading, writing, mathematical, and computer skills

- Develop study and research skills

- Gain experience in independent learning and group activities

\section{UPGRADING PROGRAM (PREPARATORY COURSES)}

Students enrolled in ENGAP who do not have the required prerequisites for engineering, or have them but with an insufficient mark, are required to enroll in the upgrading program. The upgrading program consists of five courses, four delivered through ENGAP and one delivered through the University. The four courses delivered through ENGAP are: Preparatory Physics 1, Preparatory Physics 2, Pre-Calculus Math, and Introductory Computer Programming. The upgrading course they take through the general University system is Preparatory Chemistry. These courses do not count for credit toward their Engineering Degree. There is no tuition fee for the courses offered through ENGAP and the class size is limited to ENGAP students. The chemistry course they take through the University is with other University students and has a tuition fee associated with it.

ENGAP students take their upgrading courses interspersed with regular engineering courses for funding reasons. Therefore ENGAP students generally take two years to complete the first year of engineering. The upgrading courses are concentrated in first term (September to December) so that typical students will take the Preparatory Chemistry Course, Introductory Physics 1, and the Pre-Calculus Math course in the first term along with one first year engineering course, such as Engineering Design. In second term (January through April) students will take either Preparatory Physic 2 or Introductory Computer Programming (these courses alternate with each other every other year) along with three first year engineering courses including Calculus 1 if they have successfully passed the Pre-Calculus course. 


\section{CALCULUS 1}

In addition to teaching the Pre-Calculus Math course, ENGAP's Undergraduate Co-ordinator also teaches Calculus 1 to the ENGAP students. Calculus 1 is one of the fundamental courses in engineering and therefore ENGAP has received permission from the math department to teach this course. We limit class size to ENGAP students and also expand the contact hours between the students and the instructor to 6 hours per week from the normal 4 . This allows the class to proceed at a slower pace and gives the students a better grasp of the material. Additionally unlike the standard Calculus Course where there is one or perhaps two terms tests and a final the ENGAP Calculus Course has numerous unit tests (generally one each week), a mid term, and a final.

\section{SUPPORTS}

ENGAP is based on a support model. There are supports offered in four broad areas: academic support, social support, personal support, and financial support.

Academically ENGAP assists the students first and foremost by offering the upgrading courses that allow students the opportunity to enter the faculty.

During their academic careers students can access tutors for the various courses required to complete an engineering degree. The tutors are paid through ENGAP and therefore students incur no costs for using them. Each ENGAP student is allowed to utilize three hours of tutors per week.

The Undergraduate Coordinator assists the students in course selection, timetable planning, as well as registration.

ENGAP has a personal counselor whose role is to assist students with any transitional issues that they may face. Students that are entering the University for the first time may encounter many issues. They may feel inadequate to the task of completing a degree, or they may feel unprepared for this undertaking. High school may not have prepared them for the level of research or writing required. They may also have personal issues that must be resolved before they can become a successful student.
ENGAP offers a large lounge and study areas where students can either relax in a safe comfortable environment, complete assignments, or work with tutors one on one.

There is a computer lab where students can access the internet and printers for their school work.

Within ENGAP there are many opportunities for positive social interactions for students. Exam breakfasts, monthly student/staff lunches, Christmas Party, and graduation ceremony are a few such social activities our students can participate in.

A number of years ago ENGAP created a scholarship and bursary program. This program assists students financially. Additionally ENGAP students that take out a Canada Student Loan are eligible for an Access Bursary which can replace $50 \%$ of their loan with a non-repayable bursary.

\section{SUCCESS}

Since the program first started in 1985 until 2011 ENGAP has had 85 graduates of Aboriginal descent. It is the most successful program of its type in Canada. Over the last several years between four and seven ENGAP students have graduated each year.

\section{Acknowledgements}

This program would not be possible without the continued supports of the Council of Post-Secondary Education, The Faculty of Engineering and the University of Manitoba.

ENGAP also thrives because of the dedication of its staff: Diana Klassen, Kristen Olson, and Tannis Geddes.

The following corporations provide funding for the ENGAP scholarship and bursary initiative; APEGM, Golder Associates, Hatch Ltd, Manitoba Hydro, PetroCanada, Manitoba Aerospace Human Resources Council (StandardAero, Magellan Aerospace/Bristol Aerospace Ltd, Boeing Canada technology), Nexen Inc, Shell Canada. 